Biofortification of feedstuffs with microelements in animal nutrition

Biofortifikacija krmiva mikroelementima u hranidbi domaćih životinja

Novoselec, J., Klir, Ž., Domaćinović, M., Lončarić, Z., Antunović, Z.

Poljoprivreda/Agriculture

ISSN: $1848-8080$ (Online)

ISSN: 1330-7142 (Print)

http://dx.doi.org/10.18047/poljo.24.1.4

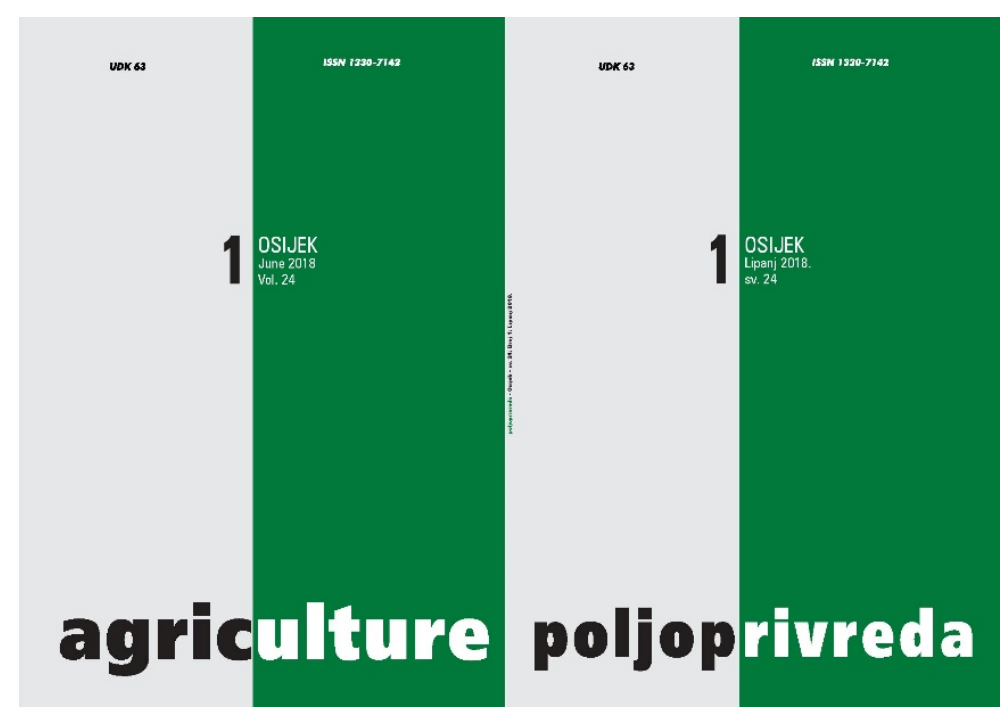

Poljoprivredni fakultet u Osijeku, Poljoprivredni institut Osijek Faculty of Agriculture in Osijek, Agricultural Institute Osijek 
ISSN $1330-7142$

UDK: 636.084 .42

DOI: $10.18047 /$ poljo.24.1.4

\title{
BIOFORTIFICATION OF FEEDSTUFFS WITH MICROELEMENTS IN ANIMAL NUTRITION
}

Novoselec, J., Klir, Ž., Domaćinović, M., Lončarić, Z., Antunović, Z.

\author{
Scientific review \\ Pregledni znanstveni članak
}

\begin{abstract}
SUMMARY
Continuous growth of human population, combined with the changes in eating habits, calls for an intensification of agricultural production. However, apart from the increase in food production, its nutritional composition is important as well, particularly in terms of microelements. In diets of over two thirds of the world's population, there is a lack of more than one microelement. Insufficient concentrations of microelements, which are important for proper growth, development and health of humans and domestic animals, can be eliminated with diverse nutrition, microelement supplementation and by increasing the concentration and bioavailability of microelements in feeds used in animal nutrition, or biofortification. By reviewing the literature, the factors that influence the increase in microelement concentration in fodder crops are presented. Agronomic and genetic approach to biofortification is advocated as an immediate strategy to eliminate the lack of microelements most commonly lacking in diets: iron (Fe), copper (Cu), zinc (Zn), iodine (I), selenium (Se). The nutrition of animals containing biofortified fodder aims to increase the concentration of the aforementioned microelements in blood and improve their growth, development and health. By increasing the concentrations of microelements in tissues and milk of domestic animals, the ultimate goal is to meet the microelement needs in humans.
\end{abstract}

Key-words: biofortification, microelements, fodder crops, animals

\section{INTRODUCTION}

More than 22 different microelements are needed for normal function of the human organism (Graham et al., 2007). Some of them are required in larger quantities, while others like iron (Fe), copper (Cu), zinc (Zn), iodine (I) and selenium (Se) are required in traces because they are poisonous in larger quantities (Grusak and Cakmak, 2009). These elements are very important for human health, and in many cases, they manage body and mental development and the way humans respond to disease (Dimkpa and Bindraba, 2016). Many enzymes, proteins, and other biological compounds that control important biological functions in humans are not fully functional if there is a lack of microelements. It is estimated that about half of the human population suffers from the lack of Fe and $\mathrm{Zn}$.
The lack of $\mathrm{Fe}$ and $\mathrm{Zn}$ is the most widely known in the world as "hidden hunger", and causes slower growth and psychomotor development in children, weaker immunity, decreased muscle mass, hair loss, infertility, and in acute cases even death (Stein, 2010). Over 30\% of the human population suffers from I deficiency, and $15 \%$ from the lack of Se. The lack of $\mathrm{Cu}$ is most common in developed and developing countries (Rawat et al., 2013). People ingest these microelements through a variety of foods of plant and animal origin. However, microelements are often present in insufficient amounts in the soil, in fodder crops, animals and ultimately in the

Assist. Prof. Josip Novoselec (jnovoselec@pfos.hr), Želika Klir, Ph.D., Prof. Dr. Matija Domaćinović, Prof. Dr. Zdenko Lončarić, Prof. Dr. Zvonko Antunović - Josip Juraj Strossmayer University of Osijek, Faculty of Agriculture in Osijek, Vladimira Preloga 1, 31000 Osijek, Croatia 
food of end users - humans. Changes in dietary habits of humans and a diet based on processed cereals, which have low concentrations of minerals in general, together with the lack of fish, fruit and foodstuff of animal origin, greatly contribute to the problems associated with the lack of microelements (White and Broadley, 2009; Gomez-Galera et al., 2010). Anti-nutrition factors, such as phytic acid, fibres and tannins, further reduce the bioavailability of food microelements by preventing their absorption in the intestines (Pfeiffer and MacClafferty, 2007). The lack of these microelements in food or microelements malnutrition, can be overcome by a nutrition variety, by supplementing micronutrients in people's usual dietary intakes, by enriching the food with specific minerals (fortification) and by increasing the concentration of minerals in edible crops (biofortification) (Stein, 2010). Each of the above mentioned approaches has its own advantages and disadvantages, and the correct combination of them all should solve the problems of mineral malnutrition. Dietary modification and diversification, as well as introducing foods that provide highly bioavailable micronutrients, is expensive (Zimmerman and Hurra, 2007). In addition, medical supplementation refers to the oral delivery of a particular microelement in the form of tablets or syrups, and is most widely used in cases of chronic deficiency. Enrichment or fortification is an addition of a particular microelement to foodstuffs such as iodine in salt, iron in flour or fluorine in toothpaste (Rawat et al., 2013). The main disadvantage of dealing with the lack of a particular microelement in these ways is the limited stability of these elements in the foodstuffs (Allen, 2003). For example, iron in food is susceptible to oxidation and altering the taste of the food. This method (fortification) of eliminating the deficiency is quite expensive, requires a well-developed distribution system, and a very precise and careful application or dosage because excessive quantities can be very harmful (Rawat et al., 2013). Biofortification refers to the application of mineral fertilisers to desired crops, in combination with breeding crop lines with increased ability to uptake microelements as an approach not only to increase the concentration of microelements in edible crops but also to improve yield on soils where microelements are in insufficient amounts or unavailable to plants (Borg et al., 2009). According to Dimkpa and Bindraban (2016), microelements in different crops increase their yield, biomass produce, dryness resistance, insecticides resistance and improve nutritional value by $10 \%$ to $70 \%$. Since microelements in edible parts of biofortified crops have to be bioavailable, comparative efforts are being made to increase the concentration of substances that stimulate the absorption of microelements in the intestine, such as ascorbate (vitamin C), $\beta$-carotene, cysteine rich polypeptides, certain organic and amino acids (White and Broadley 2009). Furthermore, at the same time it is important to reduce the concentration of micronutrient inhibitors, such as oxalate, polyphenols or phytate (Bechoff and Dhuique-Mayer, 2017).

\section{BIOFORTIFICATION OF CROPS}

Biofortification of crops with essential microelements relies on the increased absorption of these elements from the soil, but if they are not present in the soil in sufficient quantities, these microelements must be added as fertilisers. If microelements are present in the soil in sufficient quantities, then attention is focused on the bioavailability of these elements in the rhizosphere, their absorption and redistribution into edible parts of the crop in a non-toxic form (White and Broadley, 2009). In order to increase the concentration of microelements in edible tissues, without the loss of yield, the absorption of available microelements from the soil through root or leaves must be increased.

\section{AGRONOMIC APPROACH OF BIOFORTIFICATION}

Agronomic biofortification of increasing the concentration of microelements in edible plant tissues relies on the application of mineral fertilisers and/or improved solubility and mobilization of already present microelements in the soil. When plants are grown on soil where microelements are unavailable, the target application of soluble inorganic fertilisers is carried out over roots or leaves. In situations where microelements are not readily translocated in edible tissues, the application of soluble inorganic fertilisers through the leaves is carried out. According to Rengel et al. (1999), large amounts of Fe are often present in the soil, but small amounts of these are phytoavailable. Fertilisation of such soil with inorganic Fe fertilisers is usually ineffective through the absorption, precipitation and oxidation reaction. Because of this reason, Fe-chelates are often used as $\mathrm{Fe}$ fertiliser. According to Shuman (1998), the availability of $\mathrm{Fe}$ in the rhizosphere can be increased by acidification of the soil with elemental sulphur. The application of $\mathrm{Fe}$ fertiliser through leaves is carried out in plants grown on soils which are deficient in $\mathrm{Fe}$, but due to the fact that $\mathrm{Fe}$ is difficult to distribute within a plant, it must be repeated during the vegetation season (Cakmak, 2002). According to Cakmak (2008), $\mathrm{Zn}$ is usually applied to plants as $\mathrm{ZnSO}_{4}$ or in the form of synthetic chelates. An effective way of increasing $\mathrm{Zn}$ concentration in grain cereals is the application of $\mathrm{Zn}$ fertilisers to soil. Concentration of $\mathrm{Zn}$ in plants, except for application of $\mathrm{Zn}$ fertilisers in soil can be increased by foliar application of either $\mathrm{ZnSO}_{4}$ or $\mathrm{Zn}$-chelate and appropriate $\mathrm{Zn}$ tissue mobility. According to Rengel et al. (1999) and Broadley et al. (2006), application of $\mathrm{Zn}$ fertilisers through roots or foliage can increase the concentration of $\mathrm{Zn}$ in leaves, tubers, and fruits. The residual effects of $\mathrm{Zn}$ fertiliser on plants may also be visible several years after application. Bioavailability of $\mathrm{Cu}$ on many agricultural surfaces is low and $\mathrm{Cu}$ applied to the soil often remains unavailable to plants (Gupta, 1979). However, the concentration of $\mathrm{Cu}$ in cereals, vegetables and fruit can possibly be increased by application of $\mathrm{CuSO}_{4}$ or sewage sludge and manure. These fertilisers improve the rate of plant growth on soils with low Cu bioavailability and increase 
the concentration of $\mathrm{Cu}$ in edible tissues. However, one should be careful in regard to the plant variety as well as the dosage of Cu fertilisers because too large doses of Cu may be poisonous to plants and humans (Puig et al., 2007). Concentration of Se in plant tissues can be increased by applying Se fertilisers to soil or through leaves, which has a beneficial effect on animal and human health (Rayman, 2008). Most research and success in Se fertilisation was conducted in Finland and New Zealand. In Finland, since the start of Se fertilisation, the concentration of Se in food was increased by 10 times. By using sodium selenate $\left(\mathrm{Na}_{2} \mathrm{SeO}_{4}\right)$ and potassium selenate $\left(\mathrm{K}_{2} \mathrm{SeO}_{4}\right)$, Se is immediately available for crop uptake, while using selenite or less soluble form of selenate, such as barium selenate $\left(\mathrm{BaSeO}_{4}\right)$ ensures a long lasting effect (Broadley et al., 2006). Soil fertilisation with Se fertilisers is most often applied in late seasonal crops subject to moisture or heat stress, but the foliar application has also been widespread. According to Terry et al. (2000), Se-rich straw of plants which grow on seleniferous soils (increased selenium levels) can also be used as "green fertilisation" in areas with the inadequate level of Se. An increase in iodine (I) concentration is carried out by fertilisation with soluble iodide and/or iodine salts. According to Lyons et al. (2004), a successful method of increasing I concentration in edible crops and delivering I to humans is iodination of irrigation water. According to Graham et al. (2007), given that the human dietary I requirements are low, I fertilisers might be applied on large agricultural areas using airplanes.

\section{GENETIC APPROACH IN BIOFORTIFICATION}

Increasing the microelements concentrations in plants through the application of mineral fertilisers can be complemented by growing crops with increased ability to acquire and accumulate these elements in their edible parts. Significant within-species genetic variations in the concentration of $\mathrm{Fe}, \mathrm{Zn}, \mathrm{Cu}$, and $\mathrm{Se}$ were found in edible tissues of crop plants. In reviewing literature, variations in concentration of $I$ in plant tissue are much fewer compared to the above mentioned microelements. However, variations which are hereditary in concentration of $I$ in the leaves of the same species of ryegrass and white clover are found, indicating that they are under the influence of genetic control (Alderman and Jones, 1967). The concentrations of $\mathrm{Fe}$ and $\mathrm{Zn}$ in grain cereal vary (1.5-4-fold) among genotypes depending on how many of them are genetically different (White and Broadley, 2009). Compared to wild grain varieties, cultivated cereals, such as wheat, have twice as high concentrations of $\mathrm{Fe}$ and $\mathrm{Zn}$ (White and Broadley, 2005). Strong correlation between Fe and $\mathrm{Zn}$ concentrations in corn, wheat, sorghum, and pearl millet was determined. This fact greatly increases the possibility of simultaneous cultivation for increased concentration of $\mathrm{Zn}$ and $\mathrm{Fe}$ in the aforementioned cultures. Wild wheat varieties have a significantly higher concentration of Se compared to cultivated varieties, which can be used in breeding programmes (White and Broadley, 2009). Large amounts of microelements can be removed with the process of polishing and milling of cereal seeds or potential food. The amount of this loss is genotype dependent (grain morphology, grain size, embryo size, number and thickness of the tissue layers) because the highest concentrations of microelements are often in the husk and aleuronic layers (Bechoff and Dhuique-Mayer, 2017). This fact can be largely used in the biofortification approach, with regard to the number of aleurone cell layers, which is cultivar dependent. According to the research of Prom-u-thai et al. (2007) the concentration of $\mathrm{Fe}, \mathrm{Zn}$, and $\mathrm{Cu}$ in maize, rice, and barley, is associated with the number of aleuronic layers that depend on varieties. Legumes usually have higher $\mathrm{Fe}$ concentration than grains. In addition, $\mathrm{Cu}$ concentration varies significantly in soybean depending on genetic diversity among species (Zia-UI-Haq et al., 2007). However, according to Yang et al. (2003), there is little information available on the within-species variations in seed concentration of $\mathrm{Se}$ and $I$ in the legumes. Concentration of $\mathrm{Zn}$ is often much higher in vegetable leaves than in grain, seeds, fruit or tubers. Large genetic variations in shoots of $\mathrm{Fe}, \mathrm{Zn}$ and $\mathrm{S}$ concentration have also been found in spinach, beet and onion (Grusak and Cakmak, 2009). The microelements of the fruit are less mobile in the tissues, and variations among cultivars are smaller. In the research of Hakala et al. (2003), the concentration of Fe and $\mathrm{Zn}$ among six strawberry cultivars differed less than two-fold, as did in fruits of the three apple varieties (Iwane, 1991). Small genetic variations in concentration of $\mathrm{Se}$ in tomato have also been observed (Pezzarossa et al., 1999).

\section{TRANSGENIC APPROACH IN BIOFORTIFICATION}

Transgenic approach combines agronomic and genetic biofortification, i.e. the aim is to improve the phytoavailability of microelements in the soil, their uptake from rhizosphere, the transfer to younger parts of the plants and their accumulation in edible tissues (Davies, 2007). In addition, in the transgenic biofortification approach, the aim can also be to reduce the concentration of antinutrient substances and to increase the promoter substances, which increase the absorption of microelements in the intestine (White and Broadly, 2009).

\section{SUBSTANCES AFFECTING THE ABSORPTION OF MICROELEMENTS IN THE INTESTINES}

The bioavailability of essential microelements highly depends on the presence of substances that induce or prevent their absorption in the intestines (Bohn et al., 2008). The most known substances that suppress absorption of $\mathrm{Fe}, \mathrm{Zn}$ and some other elements are phytates from cereal grains and legumes seeds, and polyphenols of tea, coffee beans and sorghum. Substances that improve the absorption of $\mathrm{Fe}$ and $\mathrm{Zn}$ are ascorbic acid and $\beta$-carotene from fruits and vegetables, while cysteine rich polypeptides from plant 
and animal origin improve the absorption of $\mathrm{Fe}, \mathrm{Zn}$ and $\mathrm{Cu}$. Significant variations in the phytate concentration were found between cereals, legumes and vegetables. In addition, significant variations have been found in the concentration of phytate in the grain within the species of rice, wheat, barley, oats, triticale, sorghum, bean, soybean and rapeseed (White and Broadly, 2009). Concentrations of $\beta$-carotene and ascorbic acid vary considerably with respect to plant tissue and plant species. Concentration of $\beta$-carotene and ascorbic acid significantly increases with the aging of fruits and vegetables, and varies depending on the stage of development, part of the day, place of growth and intensity of light (Smith et al., 2007).

\section{DISTRIBUTION AND SPECIES OF MINERALS IN BIOFORTIFIED PLANTS}

Plants convert the inorganic form of Se into organic form of Se by incorporating it into proteins (Gibson et al., 2006). The first step is the reduction of $\mathrm{Se}^{6+}$ to $\mathrm{Se}^{4+}$, and this process takes place in leaves of plants. Selenite is then readily incorporated into the organic compounds, primarily in the form of selenoether amino acids R-Se-R, some of which function as Se analogues of essential sulphur compounds. Some of the most important Se analogues of essential sulphur compounds are Se-methylselenocysteine, selenocystathione and Se-methylselenomethionine. These Se-amino acids are extensively incorporated into plant proteins (Mikkelsen et al., 1989). In research of Galinha et al. (2015), the positive effect of agronomic biofortification of wheat with selenium was determined not only on the total concentration of Se in wheat, but also on the concentration of the chemical form of Se. Namely, regardless of the Se form used for wheat fertilisation, $100 \mathrm{~g} / \mathrm{ha}$ of sodium selenate (active form $\mathrm{Se}^{6+}$ ) or sodium selenite (active form $\mathrm{Se}^{4+}$ ), and the application method (soil or leaves), almost $100 \%$ organic form of Se selenomethionine (SeMet) was found in the grain of wheat. These results are similar to those of Cubadda et al. (2010) and Hart et al. (2011), who in a similar fertilisation trial found $75 \%$ and $60 \%$ of total Se in the form of selenomethionine in the wheat flour. In the leafy fertilisation of barley with sodium selenate at concentrations of $0,40,80$ and $160 \mathrm{~g} / \mathrm{ha}$, linear growth of Se concentration in the grain was determined (Gibson et al., 2006). The inorganic Se has been converted into organic form predominately selenomethionine. Same authors have found that the concentration of $\mathrm{Se}$ is similar in the distal and embryo ends of the barley grain, as well as in pearled grain and its husks, which indicates the same distribution of $\mathrm{Se}$ in the entire grain. Compared with $\mathrm{Se}, \mathrm{Zn}$ is much more unevenly distributed in the grain. This fact points to a little loss of Se in various biofortified grains during wheat milling into flour, rice polishing or barley pearling. In the research of Cakmak (2010), a three-fold increase in $\mathrm{Zn}$ concentration in wheat grain was determined in combined treatment of soil and leaves with zinc ferti- liser $\mathrm{ZnSO}_{4}$. The author also determined the positive influence of $\mathrm{Zn}$ fertilisation on wheat grain yield if it is grown on a soil where $\mathrm{Zn}$ deficiency is established. Foliar $\mathrm{Zn}$ application resulted in significant increases in $\mathrm{Zn}$ grain concentration. Enrichment of wheat grain with $\mathrm{Zn}$ is even more evident when plants have enough nitrogen $(\mathrm{N})$ available through soil or by treating the leaves (urea). Cakmak (2010), contrary to the results obtained when using Zn-fertiliser, did not establish a positive effect on the concentration of $\mathrm{Fe}$ in the wheat grain when fertilising either soil or leaves with Fe-fertiliser. Increased deposition of $\mathrm{Fe}$ in wheat grain was determined when Fe-fertiliser in combination with $\mathrm{N}$ was administered. As in the case of $\mathrm{Zn}$, there was a positive correlation between $\mathrm{Fe}$ and $\mathrm{N}$ concentrations in wheat tissue. The target application of fertiliser by leaf or foliar application in relation to soil treatment is more effective, and avoids complicated soil reactions and different uptake of microelements due to various environmental and soil conditions.

\section{SELENIUM BIOFORTIFICATION OF CERTAIN FEEDSTUFF}

Watkinson and Davis (1967) determined good absorption and distribution of Se within the entire plant by treating the leaves of clover with selenite in the form of solutions. In leaf-treated clover, the concentration of Se was 5 times higher than that in a clover, which grew in the soil treated with selenium. Rodrigo et al. (2013) determined a significant influence of the chemical form of Se-fertiliser (sodium selenate and sodium selenite) after the leaf application of barley at different doses by two seasons in the Mediterranean conditions. Selenate is, compared to selenite, significantly better adopted. They found a strong linear relationship between the total concentration of Se in grain and the dose of selenium fertiliser in both selenate and selenite. However, a significant increase in the concentration of $\mathrm{Se}$ in the grain was determined during the fertilisation with selenate. The total amount of Se in the grains of barley was about $69 \mu \mathrm{g} / \mathrm{kg}$ dry weight (DW) at doses of 0 , and $520-2336 \mu \mathrm{g} / \mathrm{kg} \mathrm{DW}$ at dosage of $40 \mathrm{~g} / \mathrm{ha}$ of selenite or selenate, respectively. Concentration of Se in barley grain, increased by 55 and $33 \mu \mathrm{g} / \mathrm{kg}$ DW and 10 and $6 \mu \mathrm{g} / \mathrm{kg}$ DW for each $\mathrm{g} / \mathrm{ha}$ of Se applied as a fertiliser in the form of sodium selenite or sodium selenite. This means that the application of selenate at a dose of less than $10 \mathrm{~g} / \mathrm{ha}$ may provide one $\mathrm{kg}$ of barley with a concentration of Se in grain higher than 200-300 $\mu \mathrm{g} / \mathrm{kg} \mathrm{DW}$. This is the minimum Se concentration that sheep and cattle require to prevent Se deficiency diseases (NRC, 1996). At the same time, after harvesting, no increased concentrations of total or bioavailable Se were found in the soil, not even at the highest doses of fertilisation. The research of Chilimba et al. (2011) was conducted on corn and determined linear increase in grain Se concentration after fertilisation with selenate. Corn was treated with liquid drench of $\mathrm{Na}_{2} \mathrm{SO}_{4}$, com- 
plex fertiliser in the form of granules NPK+Se fertiliser, or Se-enriched calcium ammonium nitrate $\mathrm{CAN}+\mathrm{Se}$. Average growth of Se concentration in corn grain was 20,21 and $15 \mu \mathrm{g} / \mathrm{kg}$ for each gram where Se was applied as $\mathrm{Na}_{2} \mathrm{SeO}_{4}, \mathrm{NPK}+\mathrm{Se}$, CAN+Se respectively. The authors did not determine the effect on grain and stover yields. McDowell et al. (2002) treated bahiagrass (Paspalum motatum) and fescue (Festuca spp.) with liquid selenium fertiliser (Selcote Ultra) at different rates. In the bahiagrass, Se concentrations were highest in the samples taken in the fourth and sixth week after spraying with fertiliser at concentrations of 5,10 and $20 \mathrm{~g} / \mathrm{ha}$ of $\mathrm{Se}$, while in the samples sprayed with a dose of 15 $\mathrm{g} / \mathrm{ha}$ the highest selenium concentration presented two weeks after spraying, after which it declined. In fescue, the highest concentration of selenium was determined 2 weeks after fertilisation with Selcote Ultra and then the concentration steadily decreased from $4^{\text {th }}$ to $16^{\text {th }}$ week, and this trend continued on to the $22^{\text {nd }}$ week after the treatment. Tremblay et al. (2014) fertilised timothy (Phleum pratense L.) with liquid selenium fertiliser and determined the linear increase of Se concentration in the timothy with increasing Se rates, with which they treated meadow. Fertilisation did not affect timothy dry matter (DM) yield, fibre concentration, and digestibility. Spraying applications of $10 \mathrm{~g} \mathrm{Se} / \mathrm{ha}$ are sufficient to produce timothy with adequate Se concentration to prevent deficiency diseases in livestock. Filley et al. (2007) found that fertilisation of perennial ryegrass (Lolium perene) and subterranean clover (Trifolium subterranean) by foliar application of sodium selenite and sodium selenate is an efficient method of raising the forage Se concentration for up to two years. Sodium selenate compared to other treatments provided greater $(P<0.01)$ average forage Se concentrations in the first year.

\section{SELENIUM BIOFORTIFIED FEEDSTUFF IN ANIMAL NUTRITION}

Research objective of Hall et al. (2009) was to compare the status of Se in sheep after short exposure to the foliar fertilised pasture with high dosage of selenium to sheep that had obtained the usual mineral supplement of selenium (sodium selenite). Whole-blood Se concentrations were higher $(\mathrm{P}<0.0001)$ immediately post-treatment in sheep grazing Se-fertilised forage (573 $\mathrm{ng} / \mathrm{ml}$ ) compared to sheep receiving mineral supplement containing Se $(286 \mathrm{ng} / \mathrm{ml})$. Also, the concentration of Se in the whole blood was still significantly higher $(P<0.0001) 9$ months later in the sheep grazing $(97 \mathrm{ng} /$ $\mathrm{ml}$ ) compared to the sheep that had available mineral Se supplement $(61 \mathrm{ng} / \mathrm{mL})$. For a significantly $(P<0.0001)$ longer period, the concentration of Se in whole blood was within the normal reference values in pasture sheep (243 days) compared to sheep receiving mineral supplement containing inorganic Se (163 days). Seboussi et al. (2016) found increased bioavailability of Se in milk and blood of cows that were fed with high-Se silage obtained by foliar fertilisation with $2.5 \mathrm{~kg} / \mathrm{ha}$ Secolte Ultra, compared to cows fed with low-Se silage and addition of inorganic $\mathrm{Se}$, and cows fed with low $\mathrm{Se}$ silage and addition of organic Se from yeast. The Se from the biofortified silage had a higher bioavailability compared to the Se from selenized yeast. Cows fed with high-Se silage extracted up to $22 \%$ less Se (compared to the intake) and had a $16 \%$ higher Se concentration in serum and $11 \%$ in milk compared to cows that had available Se from selenium yeast. Also, cows fed with biofortified silage had a higher protein concentration in milk $(3.51 \%)$ compared to cows fed with low-Se silage and inorganic selenium $(3.44 \%)$, but little lower compared to those fed with low-Se silage and selenium yeast (3.58\%). Hall et al. (2011) found that after the short-term exposure to Se-fertilised forage cows had a higher concentration of Se in the blood and better humoral immunity compared to cows that had limited access (6 weeks) to feed with mineral supplement of $\mathrm{Se}$, and a group that had unlimited access to the feed with mineral supplement of Se. The cows grazed for 6 weeks Se-fertilised forage on pasture treated with Secolte Ultra $(10 \mathrm{~g} \mathrm{Se} / \mathrm{kg}$ as sodium selenate) mixed with nitrogen fertiliser and applied at rate $3.4 \mathrm{~kg} / \mathrm{ha}(34 \mathrm{~g} \mathrm{Se} / \mathrm{ha})$. Before fertilisation forage, Se concentration was 0.11 $\mathrm{mg} / \mathrm{kg}$ DM basis, after 62 days of fertilisation when the dry cows began grazing the pasture Se concentration was $1.52 \mathrm{mg} / \mathrm{kg}$, and 42 days later, when the dry cows were removed from the pasture, it was $1.06 \mathrm{mg} / \mathrm{kg}$. Cows were immunized with bacteriocin Escherichia coli at the end of the 6-week supplementation period. The cows that grazed biofortified forage had a higher $(\mathrm{P}<0.0001)$ whole blood Se concentration $(186 \mathrm{ng} / \mathrm{mL})$ immediately post-grazing compared to cows with a limited mineral Se supplement $(117 \mathrm{ng} / \mathrm{mL})$, and cows with unlimited access to the mineral supplement Se $(130 \mathrm{ng} / \mathrm{ml})$. Whole blood Se concentration in cows that grazed biofortified forage remained higher over the next 4 months compared to the cows with unlimited mineral Se supplement, and 5 months compared to cows with limited mineral Se supplement. Over the 4 months, $E$. coli antibody titres were higher in cows having biofortified forage than in cows with limited mineral Se supplement. Selenium is an essential microelement in suckling calves, particularly in the transition stage between weaning and movement to feedlot, and its deficiency contributes to lower vitality and an increased calf mortality rate as determined by many researchers. The objectives of the study of Hall et al. (2013a) were to evaluate whole blood Se concentration and performance in weaned calves fed alfalfa hay fertilised with $\mathrm{Se}$ at increasing rates for 7 weeks. Selenium content in alfalfa hay increased linearly in a dose dependent manner from 0.07 to $0.95,1.55$ and $3.26 \mathrm{mg} \mathrm{Se} / \mathrm{kg} \mathrm{DM}$ for sodiumselenate application rate of $0,22.5,45,89.9 \mathrm{~g} \mathrm{Se} / \mathrm{ha}$, respectively. Heifer calves had greater whole blood $\mathrm{Se}$ concentration compared to male calves. The body weight response increased $(P<0.001)$ with greater amounts of sodium selenate applied to the meadow or 
soil, but there was no significant difference between the sexes $(P=0.98)$. Wallace et al. (2017) found linearly increased Se concentrations in whole blood $(\mathrm{P}<0.001)$ and colostrum $(\mathrm{P}<0.001)$ of cows and in whole blood of newborn calves $(P<0.001)$ fed with increasing Se concentrations in alfalfa hay. Cows were fed with Se-enriched hay during last 8 to 12 weeks of gestation. Authors determined increased colostral lgG1 concentrations after feeding cows with Se-fertilised hay for 8 do 97 weeks. Colostral IgG1 concentrations were in positive correlation with whole blood Se concentration and tend to be associated with colostral Se concentrations. Antibody of $E$-coli in colostrum followed the same trend as colostral $\operatorname{lgG} 1$. Concentrations of $\operatorname{lgG} 1$ in calves, as well as $E$. coli antibody, were not affected by Se treatment. Hall et al. (2013b) test whether beef calves fed with Se-enriched alfalfa during the transition period between weaning and movement to a feedlot have improved immune response and slaughter weights. All calves were immunized with J-5 Escherichia coli bacterin. Authors determined that calves fed with highest level, compared to the lowest level, of Se-enriched alfalfa hay had higher antibody titres, thioredoxin reductase-2 mRNA levels, and a greater neutrophil total antioxidant potential. Calves fed with highest-Se level forage had lower mortality and greater slaughter weights. It is well known that selenium is a trace element important for immune function and overall health of cattle lamb, goat kid, etc. Among the many factors, nasopharyngeal microbiota plays an important role in overall respiratory health, especially when stress associated with weaning, transport, and adaptation to a feedlot affect the normal respiratory defences. Hall et al. (2017) found enriched nasal microbiota after feeding calves with alfalfa hay for 9 weeks. Namely, hay was harvested from fields after fertilisation with sodium selenite. Selenium concentrations in whole blood were dependent upon Se-application rates and increased linearly. Clostridiales and Bacteridales were increased in calves fed with high Se alfalfa hay and Lactobacillales and Flavobacteriales in healthy controls calves. Ranches et al. (2017) found greater $(P \leq 0.001)$ Se concentration in selenium fertilised forage compared to control forage without Se fertilisation (7.7 vs. $0.1 \mathrm{mg} \mathrm{Se} / \mathrm{kg} \mathrm{DM}$ ) respectively) in experiment 1 conducted to evaluate $\mathrm{Se}$ status in calves. In experiment 2 conducted to evaluate Se status in cows and newborn calves, greater $(P \leq 0.001)$ concentration of Se in selenium fertilised forage compared to control forage without Se fertilisation (10.8 vs. $0.1 \mathrm{mg} \mathrm{Se} / \mathrm{kg} \mathrm{DM})$, respectively, was also determined. Authors determined greatest liver Se concentration $(\mathrm{P} \leq 0.005)$ on day 42 for calves provided Se hay compared with calves provided sodium selenite or control group (3.1: $2.4: 0.5 \mathrm{mg} \mathrm{Se} / \mathrm{kg} \mathrm{DM}$ ). In experiment 2 , selenium supplemented cows had greater $(P \leq 0.001)$ liver, cotyledon, plasma and whole blood Se concentration compared to cows not receiving supplemental Se. Furthermore, cows provided with Se hay tend $(\mathrm{P}=0.11)$ to have greater liver Se concentration compared to cows provided sodium selenite (1.2:1.1 mg Se/kg DM). Calves born to Se-supplemented cows had greater $(\mathrm{P}=0.001)$ plasma $\mathrm{Se}$ concentration than calves born to cows receiving no supplemental Se $(22.0: 14.8 \mathrm{ng} / \mathrm{mL})$. Calves born to cows provided with Se hay tend $(\mathrm{P}=0.06)$ to have greater plasma Se concentration compared with calves born to cows provided sodium selenite (22.0 : $19.4 \mathrm{Se} \mathrm{ng} / \mathrm{mL}$ ). Lončarić et al. (2014) determined the positive effect of feeding rats with Se agrofortified wheat on Se concentration in rat tissues. Winter wheat in experimental group was foliar treated with Se by application of $\mathrm{Na}_{2} \mathrm{SeO}_{4}$ in amount of $10 \mathrm{~g} / \mathrm{he} \mathrm{Se}$. Authors determined increased (12-fold) Se grain concentration from $30 \mu \mathrm{g} / \mathrm{kg}$ to $363 \mu \mathrm{g} / \mathrm{kg}$. In addition, they determined significantly higher concentrations of selenium in the rat kidneys, skin, muscles and brain. The average increase of Se concentration in agrofortified group was $30 \%$. Stupin et al. (2017) examined whether low dietary Se content affects function and vascular relaxation of rat aortas, and tested the role of oxidative stress on the aforementioned. A total of forty rats were divided into two groups and fed with two types of custom-made rat chow for 10 weeks. The low-Se group of rats was fed with plain rat chow low in content of $S e(0.030 \mathrm{mg} / \mathrm{kg})$, and norm-Se group with rat chow with normal Se content $(0.363 \mathrm{mg} / \mathrm{kg})$. Low-Se rat chow was prepared from the standard ingredients except wheat, which was low in Se, and normal-Se group with wheat that was biofortified to the normal Se content. In the low-Se group, they determined reduced relaxation of rat aortas compared to normal-Se group of rats. Significantly, decreased content of Se in whole blood and thoracic aorta tissue (0.45; $0.12 \mu \mathrm{g} / \mathrm{ml}$ ) was determined in the low-Se group compared to the normal-Se group $(0.54 ; 0.20 \mu \mathrm{g} / \mathrm{ml})$. In the low-Se group, mRNA expression of GPx1 in rat aortic tissues was significantly reduced compared to normalSe group. Mehdi et al. (2015) researched the effects of Se enrichment of feedstuffs (barley and spelt) on the growth performance of Belgian Blue bulls, on Se content in the meet and organs, as well as on the meat quality and meat chemical composition. Bulls in the experimental group were fed with a combination of barley and spelt enriched with selenium (sodium selenate $4 \mathrm{~g} \mathrm{ha}^{-1}$ ), and in the control group with barley and spelt without Se. The authors did not determine the significant influence of biofortified grains on growth performance, slaughter characteristics or meat quality $(P>0.05)$. No effects of Se on tenderness, oxidative rancidity (TBARS) and water loss were determined. Concerning meat chemical composition, the organic matter $(\mathrm{P}<0.01)$ and ether extract content $(P<0.05)$ were lower in the muscles of bulls in the Se group compared to the control group. Similar results were observed by Netto et al. (2014) in Brangus cattle when adding $2 \mathrm{mg} / \mathrm{kg}$ of sodium selenite to their diet. Opposite results were reported in other studies on cattle (Juniper et al., 2008; Cozzi et al., 2011). Biofortified cereals significantly increased Se content in muscles Longisimus thoracis $1177: 447 \mathrm{ng} \mathrm{g}^{-1}$ $\mathrm{DM})$ and Rectus abdominis (159: $447 \mathrm{ng} \mathrm{g}^{-1} \mathrm{DM}$ ) and 
the organs, testis (2309: $\left.2070 \mathrm{ng} \mathrm{g}^{-1} \mathrm{DM}\right)$, lungs (433: $\left.860 \mathrm{ng} \mathrm{g}^{-1} \mathrm{DM}\right)$, kidney (4956: $\left.5655 \mathrm{ng} \mathrm{g}^{-1} \mathrm{DM}\right)$, liver (474: $\left.1126 \mathrm{ng} \mathrm{g}^{-1} \mathrm{DM}\right)$ and in the plasma (31:66 $\mathrm{ng}$ $\left.\mathrm{mL}^{-1} \mathrm{DM}\right)$. These results of Se distribution in organs correlate with those reported on cattle by Juniper et al. (2008) with mineral Se supplementation, and by Lawler et al. (2004) with Se enrichment wheat. Consumption of such meat or liver could provide humans with $30 \%$ to $57 \%$ of daily Se requirements.

\section{CONCLUSION}

Biofortification of crops through the application of mineral fertilisers or agrofortification (soil or foliar application) combined with breeding varieties with increased ability of uptake, could be the fastest and cheapest way to eliminate problems related to the lack of trace elements in plants, animals and people. Complete removal of microelement malnutrition is not possible through an individual scheme or method, but through an overall strategy involving multiple types of interventions depending on conditions of specific region, plant species, and animal species. Selenium biofortified feedstuffs used in animal nutrition are an effective management system for reducing problems that are related to selenium deficiency, and for increasing selenium concentration in different animal tissue and have a positive influence on health of animals. Further research is needed to clarify the application and economic relevance of Se biofortification of feedstuffs.

\section{REFERENCES}

1. Allen, L. H. (2003). Interventions for micronutrient deficiency control in developing countries: past, present and future. The Journal of Nutrition, 133(11), 3875S-3878S. https://doi.org/10.1093/jn/133.11.3875S

2. Alderman, G., \& Jones, D. I. H. (1967). The iodine content of pastures. Journal of the Science of Food and Agriculture, 18(5), 197-199. https://doi.org/10.1002/ jsfa.2740180506

3. Bechoff, A., \& Dhuique-Mayer, C. (2017). Factors influencing micronutrient bioavailability in biofortified crops. Annals of the New York Academy of Sciences, 1390(1), 74-87. https://doi.org/10.1111/nyas.13301

4. Bohn, L., Meyer, A. S., \& Rasmussen, S. K. (2008). Phytate: impact on environment and human nutrition. A challenge for molecular breeding. Journal of Zhejiang University Science B, 9(3), 165-191. https://doi. org/10.1631/jzus.B0710640

5. Borg, S., Brinch-Pedersen, H., Tauris, B., \& Holm, P. B. (2009). Iron transport, deposition and bioavailability in the wheat and barley grain. Plant and Soil, 325(1-2), 15-24. https://doi.org/10.1007/s11104-009-0046-6

6. Broadley, M. R., White, P. J., Bryson, R. J., Meacham, M. C., Bowen, H. C., Johnson, S. E., ... \& Tucker, M. (2006). Biofortification of UK food crops with selenium. Proceedings of the Nutrition Society, 65(2), 169-181. https://doi.org/10.1079/PNS2006490
7. Cakmak, I. (2002). Plant nutrition research: Priorities to meet human needs for food in sustainable ways. Plant and Soil, 247(1), 3-24. https://doi. org/10.1023/A:1021194511492

8. Cakmak, I. (2008). Enrichment of cereal grains with zinc: agronomic or genetic biofortification?. Plant and Soil, 302(1-2), 1-17. https://doi.org/10.1007/s11104007-9466-3

9. Cakmak, I. (2010, August). Biofortification of cereals with zinc and iron through fertilization strategy. In 19th World Congress of Soil Science, Soil Solutions for a Changing World (Vol. 5, pp. 1-6).

10. Chilimba, A. D., Young, S. D., Black, C. R., Rogerson, K. B., Ander, E. L., Watts, M. J., ... \& Broadley, M. R. (2011). Maize grain and soil surveys reveal suboptimal dietary selenium intake is widespread in Malawi. Scientific Reports, 1, 72. https://doi.org/10.1038/srep00072

11. Cozzi, G., Prevedello, P., Stefani, A. L., Piron, A., Contiero, B., Lante, A., ... \& Chevaux, E. (2011). Effect of dietary supplementation with different sources of selenium on growth response, selenium blood levels and meat quality of intensively finished Charolais young bulls. Animal, 5(10), 1531-1538. https://doi.org/10.1017/ S1751731111000711

12. Cubadda, F., Aureli, F., Ciardullo, S., D'Amato, M., Raggi, A., Acharya, R., ... \& Prakash, N. T. (2010). Changes in selenium speciation associated with increasing tissue concentrations of selenium in wheat grain. Journal of Agricultural and Food Chemistry, 58(4), 2295-2301. https://doi.org/10.1021/jf903004a

13. Davies, K. M. (2007). Genetic modification of plant metabolism for human health benefits. Mutation Research/Fundamental and Molecular Mechanisms of Mutagenesis, 622(1), 122-137. https://doi.org/10.1016/j. mrfmmm.2007.02.003

14. Dimkpa, C. O., \& Bindraban, P. S. (2016). Fortification of micronutrients for efficient agronomic production: a review. Agronomy for Sustainable Development, 36(1), 7. https://doi.org/10.1007/s13593-015-0346-6

15. Filley, S. J., Peters, A., Bouska, C., Pirelli, G., \& Oldfield, J. (2007). Selenium fertilization of pastures for improved forage selenium content. The Professional Animal Scientist, 23(2), 144-147. https://doi.org/10.15232/ S1080-7446(15)30954-2

16. Galinha, C., Sánchez-Martínez, M., Pacheco, A. M., do Carmo Freitas, M., Coutinho, J., Maçãs, B., ... \& Wolterbeek, H. T. (2015). Characterization of seleniumenriched wheat by agronomic biofortification. Journal of Food Science and Technology, 52(7), 4236-4245. https://doi.org/10.1007/s13197-014-1503-7

17. Gibson, C., Park, Y. H., Myoung, K. H., Suh, M. K., McArthur, T., Lyons, G., \& Stewart, D. (2006). The biofortification of barley with selenium. Proceedings of the Institute of Brewery \& Distillating (Asia-Pacific Section) Carventron, 19-24.

18. Gómez-Galera, S., Rojas, E., Sudhakar, D., Zhu, C., Pelacho, A. M., Capell, T., \& Christou, P. (2010). Critical evaluation of strategies for mineral fortification of staple food crops. Transgenic Research, 19(2), 165-180. https://doi.org/10.1007/s11248-009-9311-y 
19. Graham, R. D., Welch, R. M., Saunders, D. A., Ortiz-Monasterio, I., Bouis, H. E., Bonierbale, M., ... \& Meisner, C. A. (2007). Nutritious subsistence food systems. Advances in Agronomy, 92, 1-74. https://doi. org/10.1016/S0065-2113(04)92001-9

20. Grusak, M. A., \& Cakmak, I. (2009). 12 Methods to improve the crop-delivery of minerals to humans and livestock. Plant Nutritional Genomics, 265.

21. Gupta, U. C. (1979). Copper in agricultural crops. Copper in the environment. New York, NY, USA: John Wiley, 255-287.

22. Hakala, M., Lapveteläinen, A., Huopalahti, R., Kallio, H., \& Tahvonen, R. (2003). Effects of varieties and cultivation conditions on the composition of strawberries. Journal of Food Composition and Analysis, 16(1), 67-80. https://doi.org/10.1016/S0889-1575(02)00165-5

23. Hall, J. A., Van Saun, R. J., Nichols, T., Mosher, W., \& Pirelli, G. (2009). Comparison of selenium status in sheep after short-term exposure to high-seleniumfertilized forage or mineral supplement. Small ruminant research, 82(1), 40-45. https://doi.org/10.1016/j.smallrumres.2009.01.010

24. Hall, J. A., Harwell, A. M., Van Saun, R. J., Vorachek, W. R., Stewart, W. C., Galbraith, M. L., ... \& Pirelli, G. J. (2011). Agronomic biofortification with selenium: Effects on whole blood selenium and humoral immunity in beef cattle. Animal Feed Science and Technology, 164(3-4), 184-190. https://doi.org/10.1016/j.anifeedsci.2011.01.009

25. Hall, J. A., Bobe, G., Vorachek, W. R., Gorman, M. E., Mosher, W. D., \& Pirelli, G. J. (2013a). Effects of feeding selenium-enriched alfalfa hay on immunity and health of weaned beef calves. Biological Trace Element Research, 156(1-3), 96-110. https://doi.org/10.1007/s12011-0139843-0

26. Hall, J. A., Bobe, G., Vorachek, W. R., Gorman, M. E., Mosher, W. D., \& Pirelli, G. J. (2013b). Effects of feeding selenium-enriched alfalfa hay on immunity and health of weaned beef calves. Biological Trace Element Research, 156(1-3), 96-110. https://doi.org/10.1007/s12011-0139843-0

27. Hall, J. A., Isaiah, A., Estill, C. T., Pirelli, G. J., \& Suchodolski, J. S. (2017). Weaned beef calves fed selenium-biofortified alfalfa hay have an enriched nasal microbiota compared with healthy controls. PloS one, 12(6), e0179215. https://doi.org/10.1371/journal. pone.0179215

28. Hart, D. J., Fairweather-Tait, S. J., Broadley, M. R., Dickinson, S. J., Foot, I., Knott, P., ... \& Stroud, J. L. (2011). Selenium concentration and speciation in biofortified flour and bread: Retention of selenium during grain biofortification, processing and production of Se-enriched food. Food Chemistry, 126(4), 1771-1778. https://doi.org/10.1016/j.foodchem.2010.12.079

29. IWANE, A. (1991). Effect of cultivar and year on mineral components of apples. Nippon Shokuhin Kogyo Gakkaishi, 38(4), 329-336. https://doi.org/10.3136/ nskkk1962.38.329

30. Juniper, D. T., Phipps, R. H., Ramos-Morales, E., \& Bertin, G. (2008). Effect of dietary supplementation with selenium-enriched yeast or sodium selenite on selenium tissue distribution and meat quality in beef cattle 1 . Journal of Animal Science, 86(11), 3100-3109. https:// doi.org/10.2527/jas.2007-0595.

31. Lawler, T. L., Taylor, J. B., Finley, J. W., \& Caton, J. S. (2004). Effect of supranutritional and organically bound selenium on performance, carcass characteristics, and selenium distribution in finishing beef steers 1. Journal of Animal Science, 82(5), 1488-1493. https:// doi.org/10.2527/2004.8251488x

32. Lončarić, Z., Drenjančević, I., Popović, B., Karalić, K., Ivezić, V., Novak, S., ... \& Singh, B. R. (2014, January). Increasing selenium concentration in animal tissues by wheat agrofortification. In FEPS (Federation of European Physiological Societies) 2014.

33. Lyons, G. H., Stangoulis, J. C., \& Graham, R. D. (2004). Exploiting micronutrient interaction to optimize biofortification programs: the case for inclusion of selenium and iodine in the HarvestPlus program. Nutrition Reviews, 62(6), 247-252. https://doi. org/10.1111/j.1753-4887.2004.tb00047.x

34. McDowell, L. R., Valle, G., Cristaldi, L., Davis, P. A., Rosendo, 0., \& Wilkinson, N. S. (2002). Selenium availability and methods of selenium supplementation for grazing ruminants. In Proc. 13th Annu. Florida Rumin. Nutr. Symp., Gainesville, FL. Univ. Florida, Gainesville (p. 86).

35. Mehdi, Y., Clinquart, A., Hornick, J. L., Cabaraux, J. F., Istasse, L., \& Dufrasne, I. (2015). Meat composition and quality of young growing Belgian Blue bulls offered a fattening diet with selenium enriched cereals. Canadian Journal of Animal Science, 95(3), 465-473. https://doi. org/10.1139/CJAS-2014-114

36. Mikkelsen, R. L., Page, A. L., \& Bingham, F. T. (1989). Factors Affecting Selenium Accumulation by Agricultural Crops1. Selenium in Agriculture and the Environment, (seleniuminagric), 65-94. doi:10.2136/sssaspecpub23.c4

37. National Research Council (1996): Selenium in Nutrition. The National Academics Press, Washington.

38. Netto, A. S., Zanetti, M. A., Del Claro, G. R., de Melo, M. P., Vilela, F. G., \& Correa, L. B. (2014). Effects of copper and selenium supplementation on performance and lipid metabolism in confined brangus bulls. AsianAustralasian journal of animal sciences, 27(4), 488. https://doi.org/10.5713/ajas.2013.13400

39. Pezzarossa, B., Piccotino, D., Shennan, C., \& Malorgio, F. (1999). Uptake and distribution of selenium in tomato plants as affected by genotype and sulphate supply. Journal of Plant Nutrition, 22(10), 1613-1635. https:// doi.org/10.1080/01904169909365741

40. Pfeiffer, W. H., \& McClafferty, B. (2007). HarvestPlus: breeding crops for better nutrition. Crop Science, 47(S3), 88-105. https://doi.org/10.2135/ cropsci2007.09.0020IPBS

41. Prom-u-thai, C., Fukai, S., Godwin, I. D., \& Huang, L. (2007). Genotypic variation of iron partitioning in rice grain. Journal of the Science of Food and Agriculture, 87(11), 2049-2054. https://doi.org/10.1002/jsfa.2961

42. Puig, S., Andrés-Colás, N., García-Molina, A., \& Penarrubia, L. (2007). Copper and iron homeostasis in Arabidopsis: responses to metal deficiencies, interactions and biotechnological applications. Plant, Cell \& 
Environment, 30(3), 271-290. https://doi.org/10.1111/ j.1365-3040.2007.01642.x

43. Ranches, J., Vendramini, J. M. B., \& Arthington, J. D. (2017). Effects of selenium biofortification of hayfields on measures of selenium status in cows and calves consuming these forages. Journal of Animal Science, 95(1), 120-128. https://doi.org/10.2527/jas.2016.0943

44. Rawat, N., Neelam, K., Tiwari, V. K., \& Dhaliwal, H. S. (2013). Biofortification of cereals to overcome hidden hunger. Plant Breeding, 132(5), 437-445. https://doi. org/10.1111/pbr.12040

45. Rayman, M. P. (2008). Food-chain selenium and human health: emphasis on intake. British Journal of Nutrition, 100(2), 254-268. https://doi.org/10.1017/ S0007114508939830

46. Rengel, Z., Batten, G. D., \& Crowley, D. D. (1999). Agronomic approaches for improving the micronutrient density in edible portions of field crops. Field Crops Research, 60(1-2), 27-40. https://doi.org/10.1016/ S0378-4290(98)00131-2

47. Rodrigo, S., Santamaría, 0., López-Bellido, F. J., \& Poblaciones, M. J. (2013). Agronomic selenium biofortification of two-rowed barley under Mediterranean conditions. Plant Soil Environ, 59(3), 115-120. https:// doi.org/10.17221/691/2012-PSE

48. Séboussi, R., Tremblay, G. F., Ouellet, V., Chouinard, P. Y., Chorfi, Y., Bélanger, G., \& Charbonneau, É. (2016). Selenium-fertilized forage as a way to supplement lactating dairy cows. Journal of Dairy Science, 99(7), 5358-5369. https://doi.org/10.3168/jds.2015-10758

49. Shuman, L. M. (1998). Micronutrient fertilizers. Journal of Crop Production, 1(2), 165-195. https://doi.org/10.1300/ J144v01n02_07

50. Smith, S. E., \& Read, D. J. (2010). Mycorrhizal symbiosis. Academic Press Inc. 198-349.

51. Stein, A. J. (2010). Global impacts of human mineral malnutrition. Plant and Soil, 335(1-2), 133-154. https:// doi.org/10.1007/s11104-009-0228-2

52. Stupin, A., Cosic, A., Novak, S., Vesel, M., Jukic, I., Popovic, B., ... \& Drenjancevic, I. (2017). Reduced Dietary Selenium Impairs Vascular Function by Increasing Oxidative Stress in Sprague-Dawley Rat Aortas. International Journal of Environmental Research and Public Health, 14(6), 591. https://doi.org/10.3390/ ijerph14060591

53. Terry, N., Zayed, A. M., De Souza, M. P., \& Tarun, A. S. (2000). Selenium in higher plants. Annual Review of Plant Biology, 51(1), 401-432. https://doi.org/10.1146/ annurev.arplant.51.1.401

54. Tremblay, G. F., Bélanger, G., Lajeunesse, J., Chouinard, P. Y., \& Charbonneau, É. (2015). Timothy response to increasing rates of selenium fertilizer in Eastern Canada. Agronomy Journal, 107(1), 211-220. https:// doi.org/10.2134/agronj14.0397

55. Wallace, L. G., Bobe, G., Vorachek, W. R., Dolan, B. P. Estill, C. T., Pirelli, G. J., \& Hall, J. A. (2017). Effects of feeding pregnant beef cows selenium-enriched alfalfa hay on selenium status and antibody titers in their newborn calves. Journal of Animal Science, 95(6), 24082420. https://doi.org/10.2527/jas.2017.1377

56. Watkinson, J. A., \& Davies, E. B. (1967). Uptake of native and applied selenium by pasture species: III. Uptake of selenium from various carriers. New Zealand Journal of Agricultural Research, 10(1), 116-121. https://doi.org/1 0.1080/00288233.1967.10423082

57. White, P. J., \& Broadley, M. R. (2005). Biofortifying crops with essential mineral elements. Trends in Plant Science, 10(12), 586-593. https://doi.org/10.1016/j. tplants.2005.10.001

58. White, P. J., \& Broadley, M. R. (2009). Biofortification of crops with seven mineral elements often lacking in human diets-iron, zinc, copper, calcium, magnesium, selenium and iodine. New Phytologist, 182(1), 49-84. https://doi.org/10.1111/j.1469-8137.2008.02738.x.

59. Yang, F., Chen, L., Hu, O., \& Pan, G. (2003). Effect of the application of selenium on selenium content of soybean and its products. Biological Trace Element Research, 93(1-3), 249-256. https://doi.org/10.1385/BTER:93:1$3: 249$

60. Zia-Ul-Haq, M., Iqbal, S., Ahmad, S., Imran, M., Niaz, A., \& Bhanger, M. I. (2007). Nutritional and compositional study of desi chickpea (Cicer arietinum L.) cultivars grown in Punjab, Pakistan. Food Chemistry, 105(4), 1357 1363. https://doi.org/10.1016/j.foodchem.2007.05.004

61. Zimmermann, M. B., \& Hurrell, R. F. (2007). Nutritional iron deficiency. The Lancet, 370(9586), 511-520. https:// doi.org/10.1016/S0140-6736(07)61235-5 


\title{
BIOFORTIFIKACIJA KRMIVA MIKROELEMENTIMA U HRANIDBI DOMAĆIH ŽIVOTINJA
}

\begin{abstract}
SAŽETAK
Neprestanim rastom ljudske populacije i promjenom prehrambenih navika ljudi rastu zahtjevi za intenziviranjem poljoprivredne proizvodnje. Međutim, osim rasta proizvodnje hrane važan je i njen nutritivni sastav, osobito u pogledu mikroelemenata. U hrani dvije trećine svjetske populacije ljudi prisutan je nedostatak više od jednoga mikroelementa. Nedostatak mikroelemenata, koji su važni za pravilan rast i razvoj te zdravlje ljudi i domaćih životinja, može se ukloniti raznovrsnošću hranidbe, dodavanjem mikroelemenata u hranu te povećanjem koncentracije i bioraspoloživosti mikroelemenata u krmivima koja se koriste u hranidbi domaćih životinja, odnosno biofortifikacijom. Pregledom dostupne literature, prikazat će se čimbenici o kojima ovisi povećanje koncentracije mikroelemenata u krmnim kulturama, kao i agronomske te genetske načine biofortifikacije, kojima se nastoji ukloniti nedostatak najčešćih mikroelemenata u hrani: selena, željeza, bakra, cinka i joda. Hranidbom domaćih životinja biofortificiranim krmivima nastoji se povećati koncentracija navedenih mikroelemenata u krvi istih te poboljšati njihov rast, razvoj i zdravlje. Porastom koncentracije mikroelemenata u tkivima i mlijeku domaćih životinja nastoje se zadovoljiti njihove potrebe u ljudi.
\end{abstract}

Ključne riječi: biofortifikacija, mikroelementi, usvajanje, krmiva, domaće životinje

(Received on 27 October 2017; accepted on 23 March 2018 - Primljeno 27. listopada 2017.; prihvaćeno 23. ožujka 2018.) 